\title{
The effect of irrigation on cadmium, uranium, and phosphorus contents in agricultural soils
}

\author{
Mahdiyeh Salmanzadeh ${ }^{\mathrm{a},}$, Louis A. Schipper ${ }^{\mathrm{a}}$, Megan R. Balks ${ }^{\mathrm{a}}$, Adam Hartland ${ }^{\mathrm{a}}$, Paul L. Mudge ${ }^{\mathrm{b}}$, Ray Littler ${ }^{\mathrm{c}}$ \\ ${ }^{a}$ School of Science and Environmental Research Institute, University of Waikato, Private Bag 3105, Hamilton, New Zealand \\ ${ }^{\mathrm{b}}$ Landcare Research Manaaki Whenua Ltd., Private Bag 3127, Hamilton, New Zealand \\ ${ }^{\mathrm{c}}$ Department of Mathematics \& Statistics, University of Waikato, Private Bag 3105, Hamilton, New Zealand
}

\section{A R T I C L E I N F O}

Keywords:

Cadmium

Agriculture

Irrigation

Fertilizer

\begin{abstract}
A B S T R A C T
Cadmium (Cd) is a toxic metal which has accumulated in New Zealand agricultural soils due to phosphate fertilizer application. Understanding the contribution of plant uptake or leaching of Cd to observed Cd losses from soil is important. The concentration and distribution of Cd in irrigated and unirrigated soils with the same phosphate fertilizer history were investigated. Twenty-two pairs of soil samples from four depths $(0-0.1,0.1-0.2,0.2-0.3$ and $0.3-0.4 \mathrm{~m}$ ) were taken from irrigated and unirrigated areas in the same field on dairy farms in three regions of New Zealand. The mean concentration of Cd at depths of 0-0.1 m and 0.1-0.2 $\mathrm{m}$, as well as the cumulative masses of $\mathrm{Cd}(0-0.2,0-0.3$ and $0-0.4 \mathrm{~m})$ in unirrigated soils were significantly higher $(P<0.05)$ than in irrigated soils. The concentration of phosphorus $(\mathrm{P})$ at all depths (except for $0.2-0.3 \mathrm{~m}$ ), as well as the cumulative mass of $P$ in all depths of unirrigated soils, was also significantly higher $(P<0.05)$ than irrigated soils. However, no significant difference was detected in the concentrations of uranium (U) between irrigated and unirrigated soils. Irrigation induced a $\sim 7 \%$ Cd loss from topsoil $(0-0.1 \mathrm{~m})$, with the average rate of Cd loss from the top $0.1 \mathrm{~m}$ (due to irrigation) being $2.3 \mathrm{~g} \mathrm{ha}^{-1} \mathrm{yr}^{-1}$. This study therefore confirms that irrigation can enhance Cd mobilization, however Cd is mainly adsorbed to the surface soil.
\end{abstract}

\section{Introduction}

Cadmium (Cd) has accumulated in New Zealand (NZ) soils mainly from phosphate fertilizers (Loganathan et al., 2003; Schipper et al., 2011) which have been applied to NZ soils since the late 1800s. The dominant productive land use in New Zealand is grazed pasture which is generally accompanied by large amounts of phosphate fertilizer use (Parliamentary Commissioner for the Environment, 2004). There are concerns about the accumulation of Cd in soil because of its entry to the human food chain and potential adverse effects on health (Mortvedt, 1995). Cadmium has been described as being the trace metal of greatest concern with respect to food standards in New Zealand (Taylor et al., 2010). In order to understand the environmental fate of Cd, it is necessary to develop a full mass balance including fertilizer inputs as well as removal in products, erosion, and leaching through the profile.
The magnitude of Cd losses from soil via drainage are not well known with studies of Cd mobility in soils based largely on the mass balance approach. Many studies report minimal cadmium loss from soil. For instance, Loganathan and Hedley (1997) found that after 10 years of phosphate fertilizer application, less than $5 \%$ of applied Cd moved below $0.2 \mathrm{~m}$ and the uptake of Cd by plants ranged from 1.5 to $4.5 \%$ of total inputs. Similarly, Singh and Myhr (1997) were unable to detect downward movement of Cd through the profile of fertilized soils in Norway. Even in a loamy sand in South Carolina with a low cation exchange capacity (CEC), Cd movement below $0.15 \mathrm{~m}$ depth was negligible $(<3 \%) 30$ months after the Cd application. Despite the low CEC in the aforementioned study, $\mathrm{Fe}$ and $\mathrm{Al}$ oxides were identified as the most important adsorbents of $\mathrm{Cd}$ in these soils (Martin and Kaplan, 1998). Cadmium appears to be even more immobilized in organic soils: in a lysimeter study of Cd losses from Organic soils, the leaching of $\mathrm{Cd}$ was not significant (less than $1 \%$ of added $\mathrm{Cd}$ from

\footnotetext{
* Corresponding author.

Email address: , salmanzadeh.mahdiyeh@gmail.com (M. Salmanzadeh)
} 
phosphate fertilizer application) over 12 months (Gray and McDowell, 2016).

While the aforementioned studies reported minimal loss of Cd by leaching, several other studies have found significant movement of Cd through the soil (Nicholson et al., 1996; Zanders et al., 1999a; Gray et al., 2003b). On an Australian sandy Podzol soil, about 50\% of added Cd from fertilizer application over 20 years, had been lost from the top $0.075 \mathrm{~m}$, with only $1-5 \%$ of soluble Cd taken up by plants. Some of the added Cd had moved to a depth of at least $0.15 \mathrm{~m}$ (Williams and David, 1976). About $50 \%$ of added Cd had accumulated in the top $0.225 \mathrm{~m}$ of a NZ soil with less than $2 \%$ of Cd was taken by plants, implying that the remainder may have moved down through the soil profile (Rothbaum et al., 1986). McBride et al. (1997) also showed that 15 years after sewage sludge application, about $30 \%$ of Cd was removed from the topsoil of an orchard site in USA, which was attributed to possible leaching losses.

The majority of these previous studies were conducted on unirrigated lands and there is some evidence that increased water application through irrigation might increase $\mathrm{Cd}$ movement through topsoil due to increased infiltration (McLeod et al., 2015). The concentration of Cd in irrigated topsoils $(0-0.075 \mathrm{~m})$ of the Winchmore research farm in New Zealand (Lismore stony silt loam) was less than in non-irrigated topsoils (McDowell, 2012). Furthermore, at Winchmore, the concentration of Cd at depths of $0.075-0.15$ and $0.15-0.30 \mathrm{~m}$ in irrigated soils was higher than in non-irrigated soils suggesting movement of Cd down the soil profile (McDowell, 2012). However, the Winchmore trial was flood irrigated and therefore may not be representative of the expanding area of pastures irrigated by overhead sprinklers in New Zealand (about $74 \%$ of NZ irrigated pastures are now being sprinkler irrigated) (Heiler, 2008; Irrigation New Zealand, 2013). Reliable data on Cd losses from irrigated soils are currently lacking. Like Cd, uranium (U) is also a contaminant of phosphate fertilizers in NZ soils, and has been classified as "very toxic" (Health and Safety Executive, 1995) and is potentially mobile (Taylor and Kim, 2007). Uranium and phosphorus (P) have important roles in soils and $\mathrm{U}, \mathrm{Cd}$, and $\mathrm{P}$ are accumulating in agricultural soils from the same source (phosphate fertilizers).

The objective of this study was to determine the potential for loss of $\mathrm{Cd}, \mathrm{U}$, and $\mathrm{P}$ due to irrigation. We took advantage of the wide scale soil sampling campaign of adjacent irrigated, and unirrigated pastures, conducted by Mudge et al. (2016) that demonstrated losses of carbon and nitrogen stocks under irrigation. On each farm, both irrigated and unirrigated areas were sampled in the same field to ensure uniform fertilizer history and therefore $\mathrm{Cd}, \mathrm{U}$, and P inputs.

\section{Materials and methods}

\subsection{Site and soil}

Soil samples were taken from 22 paired irrigated and unirrigated pasture sites (grazed by dairy cattle) in three regions of New Zealand (Fig. 1). Ten cores (0.0254 m diameter) were taken from each irrigated and unirrigated areas in the same field. On six of the 22 farms, two fields were sampled, and the two irrigated samples from the two fields were combined, as were the two unirrigated samples, giving one irrigated and one unirrigated sample. Samples from each group of 10 cores were combined for each of depths of $0-0.1,0.1-0.2,0.2-0.3$ and $0.3-0.4 \mathrm{~m}$ and bulked into one composite sample for each depth. One site in the Canterbury region was sampled to only $0.3 \mathrm{~m}$ due to high stone content lower in the profile. The selection criteria considered when choosing sampling locations have been fully described by Mudge et al. (2016) along with further information on irrigation duration (ranging 3-20 years), soil orders, type of irrigation and long-term climate data (1972-2011) for each sampling site. The irrigated and unir- rigated areas within a field were identified using local knowledge, Google Earth imagery, Irrigation Resource Consents and help from rural professionals (Mudge et al., 2016). Paired sites were selected based on the following criteria: 1 . Irrigated and unirrigated areas were within $100 \mathrm{~m}$ of each other; 2 . The irrigated areas had been irrigated for at least three years, while unirrigated areas had never been irrigated; 3 . Soils and topography were the same between irrigated and unirrigated areas, and 4. Farm management (such as fertilizer application) was the same in irrigated and unirrigated areas (expect for irrigation) (Mudge et al., 2016).

\subsection{Chemical analysis}

Soil samples were digested following the method described in Salmanzadeh et al. (2016): the air dried $\left(50^{\circ} \mathrm{C}\right)$ and sieved $(<2 \mathrm{~mm})$ soil samples were digested using Aqua Regia $\left(1 \mathrm{~mL} \mathrm{HNO}_{3}\right.$ and $0.33 \mathrm{~mL}$ $\mathrm{HCl})$ at $50^{\circ} \mathrm{C}$. After centrifuging for $10 \mathrm{~min}$ at $4000 \mathrm{rpm}$ and filtering at $0.45 \mu \mathrm{m}, \mathrm{Cd}, \mathrm{P}$, and $\mathrm{U}$ concentrations were determined using ICP-MS (Waltham, MA, USA) following calibration using NIST-traceable standards (Inorganic Ventures, Christiansburg, VA, USA). The detection limit of ICP-MS was $130 \mu \mathrm{g} \mathrm{kg}^{-1}$ for P, $6.0 \mu \mathrm{g} \mathrm{kg}{ }^{-1}$ for Cd, and $0.02 \mu \mathrm{g} \mathrm{kg}^{-1}$ for $\mathrm{U}$.

The $\mathrm{pH}$ of soil samples was measured following Blakemore et al. (1987). Total carbon (C) of the soil samples was reported by Mudge et al. (2016).

\subsection{Data analysis}

The cumulative mass of elements in each depth was calculated using the element concentration, and soil dry bulk density calculated from the mass of oven dry soil for each depth and the sample volume (depth $0.1 \mathrm{~m}$ and diameter $0.0254 \mathrm{~m}$ ).

The Minitab 17 software package and Wilcoxon signed rank test was used to test the significance of difference between the mean concentrations and cumulative mass of $\mathrm{Cd}, \mathrm{P}$, and $\mathrm{U}$ for all depths individually. The Wilcoxon signed rank test can be used to test the significance of differences when data are not normally distributed and was used to check the degree of significance in differences in $\mathrm{Cd}, \mathrm{P}$, and $\mathrm{U}$ concentrations and cumulative masses in the studied soils.

\section{Results}

\subsection{Cadmium concentration and cumulative mass}

The mean Cd concentration in unirrigated soil samples was higher $(P<0.05)$ than that for irrigated soils at depths of $0-0.1 \mathrm{~m}$ and $0.1-0.2 \mathrm{~m}$ (Table 1 ). The cumulative mass of Cd for depths of $0-0.2$, $0-0.3$ and $0-0.4 \mathrm{~m}$ in unirrigated soils was higher $(P<0.05)$ than in irrigated soils (Table 1 ).

There were no significant differences in soil dry bulk density between unirrigated and irrigated areas at the $0-0.4 \mathrm{~m}$ depth (with the mean of $1.15 \mathrm{~T} \mathrm{~m}^{-3}$ in unirrigated and $1.14 \mathrm{~T} \mathrm{~m}^{-3}$ in irrigated areas) as well as individual depths. However, soil dry bulk density at the $0-0.1 \mathrm{~m}$ depth in irrigated areas was marginally higher $(P=0.05)$ than in unirrigated areas, which may be the reason for the significant difference in Cd concentration for the top $0.1 \mathrm{~m}$ but not for total mass in the same depth (Table 1).

The number of years of irrigation may be expected to impact on the mobility of $\mathrm{Cd}$, however, there was no significant relationship $\left(\mathrm{R}^{2}=0.13, P<0.05\right)$ between irrigation duration and the amount of Cd loss from 0 to $0.4 \mathrm{~m}$ in irrigated soils (Fig. 2).

The estimation of losses of fertilizer-derived Cd from surface soils is not straight forward because the Cd content of fertilizers and the 


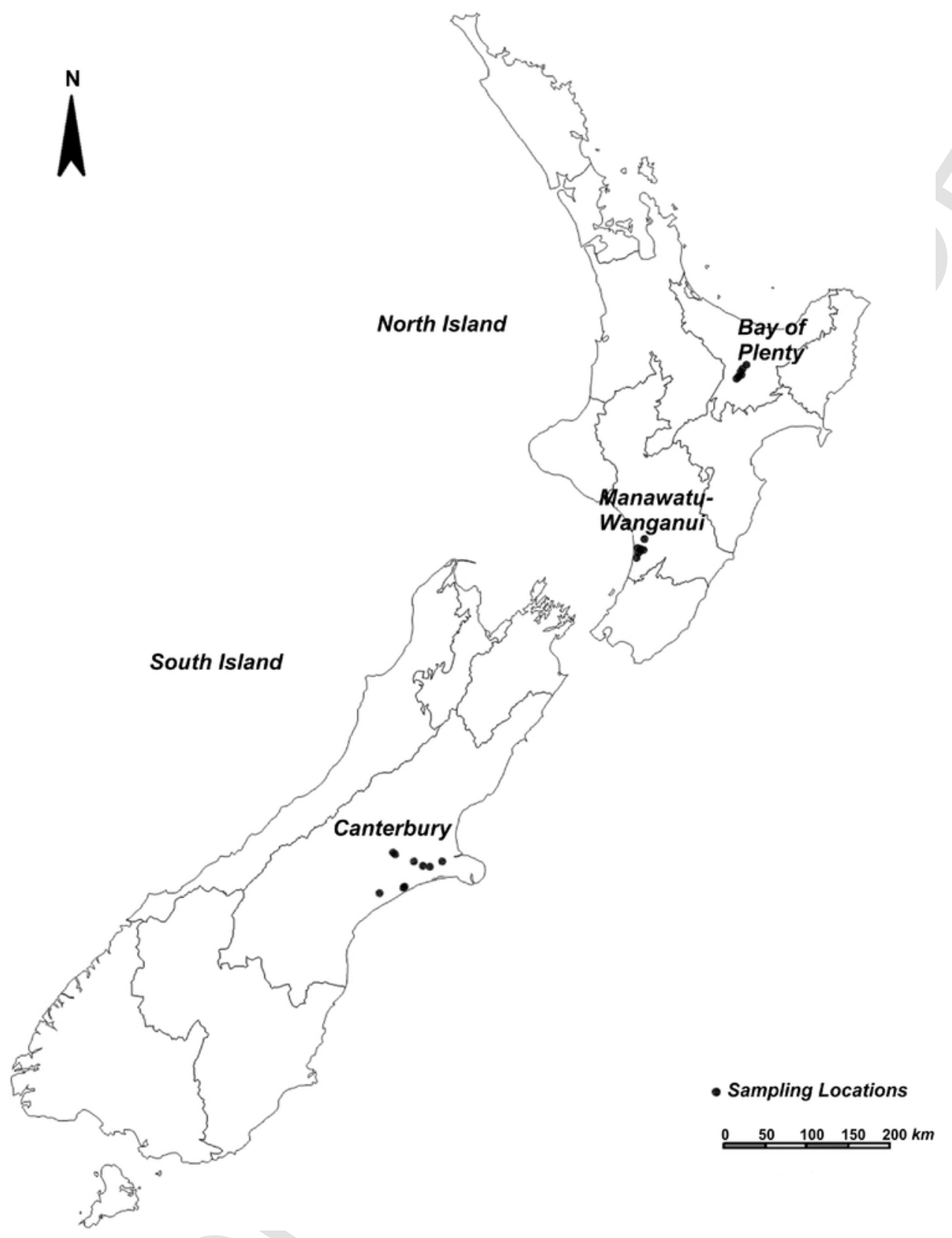

Fig. 1. Sampling locations of irrigated and unirrigated soils.

Table 1

Concentration and cumulative mass of $\mathrm{Cd}$ for different soil depths ( $P$ values $<0.05$ are bolded, numbers in the brackets are standard errors).

\begin{tabular}{|c|c|c|c|c|c|c|c|c|}
\hline \multirow[t]{2}{*}{ Depth (m) } & \multirow[t]{2}{*}{ Number of paired samples } & \multicolumn{3}{|c|}{ Mean concentration of $\mathrm{Cd}\left(\mathrm{mg} \mathrm{kg}^{-1}\right)$} & \multirow[t]{2}{*}{ Depth (m) } & \multicolumn{3}{|c|}{ Cumulative mass of $\mathrm{Cd}\left(\mathrm{kg} \mathrm{ha}^{-1}\right)$} \\
\hline & & Unirrigated & Irrigated & $P$ & & Unirrigated & Irrigated & $P$ \\
\hline $0-0.1$ & 22 & $0.33(0.04)$ & $0.29(0.03)$ & 0.023 & $0-0.1$ & $0.30(0.02)$ & $0.27(0.02)$ & 0.080 \\
\hline $0.1-0.2$ & 22 & $0.22(0.03)$ & $0.19(0.02)$ & 0.009 & $0-0.2$ & $0.54(0.04)$ & $0.48(0.03)$ & 0.003 \\
\hline $0.2-0.3$ & 22 & $0.10(0.01)$ & $0.09(0.01)$ & 0.516 & $0-0.3$ & $0.66(0.04)$ & $0.58(0.04)$ & 0.007 \\
\hline $0.3-0.4$ & 21 & $0.06(0.01)$ & $0.04(0.01)$ & 0.187 & $0-0.4$ & $0.73(0.05)$ & $0.63(0.04)$ & 0.005 \\
\hline
\end{tabular}

amount and type of fertilizers used at each site through time is not well documented. As we did not have detailed information about the fertilizer history of the sampling locations, we could not directly calculate the loss of anthropogenically added Cd in phosphate fertilizers. However, it was possible to calculate the amount and percentage of Cd loss due to irrigation using the difference in the total mass of Cd in irri- gated and unirrigated soils divided by the number of years of irrigation (3-20 years) (Table 2). To assess whether the calculated loss of Cd due to irrigation was greater than the measurement error, standard deviation of Cd determinations on paired soil samples was calculated. This standard deviation used different aliquots of the primary soil samples (independently digested by Aqua Regia and analysed by ICP-MS). This 


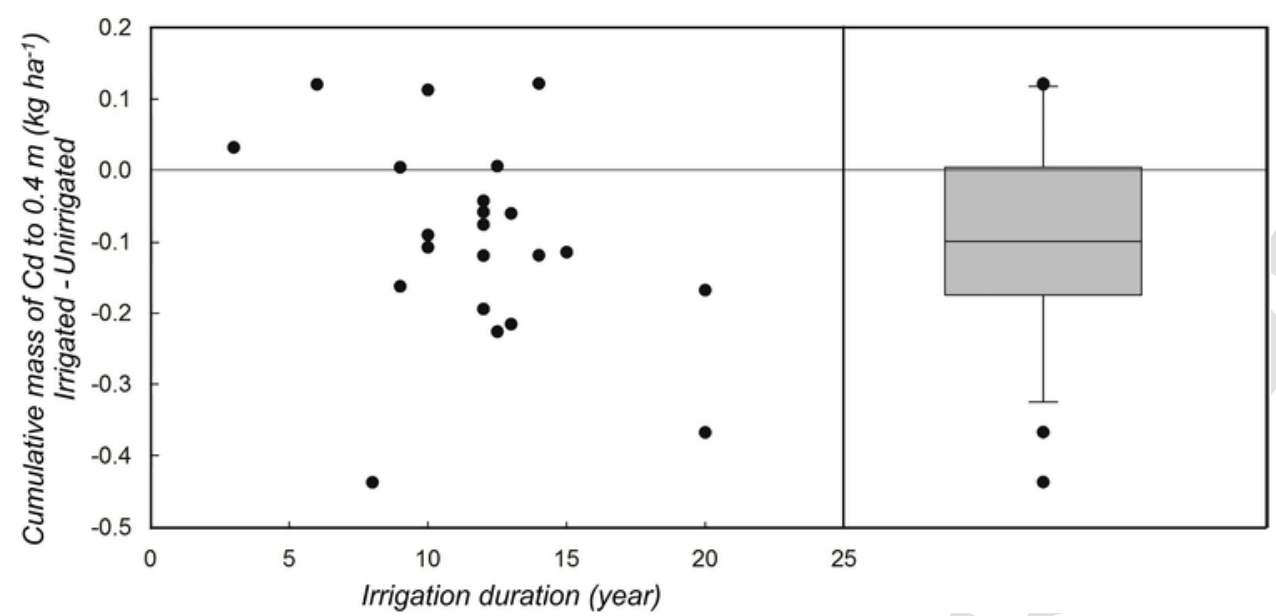

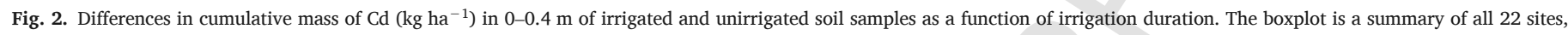
showing the median, flanked by upper and lower quartiles, the 5th and 95th percentiles as whiskers, circles are outliers.

gave a final standard deviation of $0.003 \mathrm{mg} \mathrm{kg}^{-1}$ between replicated measurements of five paired soil samples. While this measure correctly represents the measurement error for the digestion and $\mathrm{Cd}$ analysis process, it is possible that an additional error due sampling could have increased this value. This was controlled for however, by combining 10 soil samples at the time of sampling, from which a homogenised primary soil sample was generated.

The average loss of $\mathrm{Cd}$ due to irrigation was $2.3 \mathrm{~g} \mathrm{ha}^{-1} \mathrm{yr}^{-1}$ from the top $0.1 \mathrm{~m}$ and $7.2 \mathrm{~g} \mathrm{ha}^{-1} \mathrm{yr}^{-1}$ for $0-0.4 \mathrm{~m}$ (Table 2). The results of the total mass calculation showed that the maximum amount of Cd loss from the topsoil $(0-0.1 \mathrm{~m})$, due to irrigation, was about $7 \%$ and about $10 \%$ from the $0-0.4 \mathrm{~m}$ depth (Table 2 ).

The mean loss of Cd as well as the percentage of Cd removal from the $0-0.1 \mathrm{~m}$ depth was highest in the Bay of Plenty region (Pumice Soil) (Table 2). However, the mean loss and percentage of Cd removal from the $0-0.4 \mathrm{~m}$ depth was highest in the Canterbury region (Pallic, Recent, Gley, and Brown Soils) (Table 2).

\subsection{Phosphorus and uranium concentration and cumulative mass}

The concentration of $\mathrm{P}$ in the $0-0.1,0.1-0.2$ and $0.3-0.4 \mathrm{~m}$ depth intervals, as well as the cumulative mass of $\mathrm{P}$ in all depths in unirrigated soils, were significantly higher $(P<0.05)$ than in irrigated soils (Table 3). In contrast, there were no significant differences between the concentrations of $\mathrm{U}$ in irrigated and unirrigated soils. However, as for $\mathrm{Cd}$, the cumulative mass of $\mathrm{U}$ in depths of $0-0.2,0-0.3$ and $0-0.4 \mathrm{~m}$ of unirrigated soils was significantly higher $(P<0.05)$ than irrigated soils (Table 4).

There was a moderate relationship between the cumulative loss of $\mathrm{Cd}$ and the cumulative loss of $\mathrm{P}$ from the $0-0.4 \mathrm{~m}$ depth $\left(\mathrm{R}^{2}=0.25\right.$, $P<0.05$ ), however there was no significant relationship between the cumulative loss of Cd and $\mathrm{U}$.

\subsection{Soil pH and carbon content}

Overall, the mean soil $\mathrm{pH}$ was 5.6 (range 4.8-7.0) for unirrigated and 5.7 (range 4.9-6.5) for irrigated soil samples, and there were no significant differences in $\mathrm{pH}$ for either irrigated or unirrigated soil samples at any depth. The mean carbon content decreased down the soil profile and the mean carbon content in all four depths of irrigated soils was significantly lower $(P<0.05)$ than the unirrigated soil samples (full data presented in Mudge et al., 2016). There was no significant relationship between the loss of $\mathrm{Cd}$ and the difference between the $\mathrm{pH}$ in irrigated and unirrigated areas from each individual depth. There was a moderate relationship between the carbon content and Cd concentration in topsoil $(0-0.1 \mathrm{~m})$ samples $\left(\mathrm{R}^{2}=0.41, P<0.05\right)$. The cumulative loss of $\mathrm{Cd}$ and cumulative loss of $\mathrm{C}$ from 0 to $0.4 \mathrm{~m}$ were also moderately correlated $\left(\mathrm{R}^{2}=0.33, P<0.05\right)$.

\section{Discussion \\ 4.1. Cadmium, phosphorus and uranium concentration and total mass}

In comparison with previous studies of irrigation effects on Cd movement at individual sites, our analysis encompassed a broad range of soils and irrigation regimes. We measured a lower concentration of $\mathrm{Cd}$ in irrigated soil compared to unirrigated soil (0-0.1 and $0.1-0.2 \mathrm{~m}$ ), which had a mean of $0.04 \mathrm{mg} \mathrm{kg}^{-1}$ less Cd (depth of $0-0.1 \mathrm{~m}$ ). Our results were consistent with findings at the flood-irrigated Winchmore site where there was a difference of about $0.07 \mathrm{mg} \mathrm{kg}^{-1}$ in the top $0-0.075 \mathrm{~m}$ (McDowell, 2012). Because of $0.04 \mathrm{mg} \mathrm{kg}^{-1}$ of average difference between irrigated and unirrigated soils (depth of $0-0.1 \mathrm{~m}$ ) which was 13 times greater than the standard deviation $\left(0.003 \mathrm{mg} \mathrm{kg}^{-1}\right)$, the calculated losses of Cd were greater than the associated measurement error. The concentration of $\mathrm{Cd}$ in the soils sampled (mean of $0.31 \mathrm{mg} \mathrm{kg}^{-1}$ in the top $0.1 \mathrm{~m}$ of soils in our study) were relatively low in comparison to the mean concentration of Cd in topsoils of NZ dairy farms (mean of $0.58 \mathrm{mg} \mathrm{kg}^{-1}$ ) and overall in NZ pastures (0.44 $\mathrm{mg} \mathrm{kg}^{-1}$ ) (Cavanagh, 2014). However, the higher mean concentration of Cd in NZ dairy farms is due to the high concentration of $\mathrm{Cd}$ in the Waikato $\left(0.74 \mathrm{mg} \mathrm{kg}^{-1}\right)$ and Taranaki $\left(0.71 \mathrm{mg} \mathrm{kg}^{-1}\right)$ regions, which skew the mean concentration of $\mathrm{Cd}$ in NZ pastures and dairy farms. A threshold value for Cd in NZ soils of $1.8 \mathrm{mg} \mathrm{kg}^{-1}$ has been identified. If soils reach the threshold value then no further phosphate fertilizers should be applied without a site-specific investigation and risk assessment (MAF, 2011).

The lower concentration of $\mathrm{Cd}$ in the $0-0.1 \mathrm{~m}$ depth in irrigated areas than unirrigated areas was consistent with the results of McDowell (2012) who reported higher Cd concentrations in the topsoil $(0-0.075 \mathrm{~m})$ of unirrigated soils in comparison to irrigated soils. However, in the McDowell (2012) study, the irrigated subsoils (0.075-0.15 and $0.15-0.30 \mathrm{~m}$ ) contained more $\mathrm{Cd}$ than unirrigated subsoils (McDowell, 2012). McDowell (2012) reported a gradual decrease in soil $\mathrm{pH}$ at the sampled Winchmore research farm since the mid-1970s, and postulated this decrease in $\mathrm{pH}$ increased $\mathrm{Cd}$ mobility and movement deeper into the soil or uptake by plants. Also, the use of flood irrigation at Winchmore may have enhanced the leaching of Cd (Gray et al., 1999a). 


\begin{tabular}{|c|c|c|c|c|c|c|c|c|c|}
\hline Region & & Soil order ${ }^{\mathrm{a}}$ & $\begin{array}{l}\text { Irrigation } \\
\text { duration } \\
\text { (years) }\end{array}$ & $\begin{array}{l}\text { Total mass of Cd } \\
\text { in } 0-0.1 \mathrm{~m}\left(\mathrm{~kg} \mathrm{ha}^{-1}\right)\end{array}$ & $\begin{array}{l}\text { Cumulative mass of } \\
\text { Cd in } \\
0-0.4 \mathrm{~m}_{\left(\mathrm{kg} \mathrm{ha}^{-1}\right)}\end{array}$ & $\begin{array}{l}\text { Total Cd } \\
\text { removed (\%) from } \\
0 \text { to } 0.1 \mathrm{~m}^{\mathrm{b}}\end{array}$ & $\begin{array}{l}\text { Total Cd } \\
\text { removed (\%) } \\
\text { from } \\
0 \text { to } 0.4 \mathrm{~m}\end{array}$ & $\begin{array}{l}\text { Total Cd removed from } \\
0 \text { to } 0.1 \mathrm{~m}\left(\mathrm{~g} \mathrm{ha}^{-1}\right. \\
\left.\mathrm{y}^{-1}\right)^{\mathrm{c}}\end{array}$ & $\begin{array}{l}\text { Total Cd removed from } \\
0 \text { to } 0.4 \mathrm{~m}\left(\mathrm{~g} \mathrm{ha}^{-1}\right. \\
\left.\mathrm{y}^{-1}\right)\end{array}$ \\
\hline \multirow[t]{12}{*}{$\begin{array}{l}\text { Bay of Plenty } \\
\text { (BoP) }\end{array}$} & $\mathrm{Un}^{\mathrm{d}}$ & $\begin{array}{l}\text { Pumice } \\
\text { (Vitrands) }\end{array}$ & 20 & 0.50 & 1.17 & $\begin{array}{l}\left(\frac{0.05}{0.50}\right) \\
\times 100=10 \%\end{array}$ & $\begin{array}{l}\left(\frac{0.17}{1.17}\right) \\
\times 100=15 \%\end{array}$ & $\left(\frac{0.05}{20}\right) \times 1000=2.5$ & $\left(\frac{0.17}{20}\right) \times 1000=8.5$ \\
\hline & $\operatorname{Irr}^{\mathrm{e}}$ & & & 0.45 & 1.00 & & & & \\
\hline & Un & Pumice & & 0.34 & 0.65 & $5.9 \%$ & $9.2 \%$ & 1.7 & 5.0 \\
\hline & Irr & & 12 & 0.32 & 0.59 & & & & \\
\hline & Un & Pumice & & 0.41 & 0.73 & $0.0 \%$ & $11 \%$ & 0.0 & 6.7 \\
\hline & Irr & & 12 & 0.41 & 0.65 & & & & \\
\hline & Un & Pumice & & 0.64 & 0.96 & $41 \%$ & $22 \%$ & 20 & 16.1 \\
\hline & Irr & & 13 & 0.38 & 0.75 & & & 2 & \\
\hline & Un & Pumice & & 0.28 & 0.43 & $-3.4 \%$ & $-28 \%$ & -0.7 & -8.6 \\
\hline & Irr & & 14 & 0.29 & 0.55 & & & & \\
\hline & Un & Pumice & & 0.44 & 0.91 & $14 \%$ & $22 \%$ & 5.0 & 16.7 \\
\hline & Irr & & 12 & 0.38 & 0.71 & 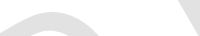 & & & \\
\hline \multirow{2}{*}{$\begin{array}{l}\text { BoP } \\
\text { (mean) }\end{array}$} & Un & & & 0.44 & 0.81 & $11 \%$ & $9.0 \%$ & 4.8 & 7.4 \\
\hline & Irr & & & 0.37 & 0.71 & & & & \\
\hline \multirow{12}{*}{$\begin{array}{l}\text { Manawatu- } \\
\text { Wanganui } \\
\text { (MW) }\end{array}$} & Un & $\begin{array}{l}\text { Brown } \\
\text { (Ochrepts) }\end{array}$ & & 0.32 & 0.70 & $28 \%$ & $17 \%$ & 6.4 & 8.6 \\
\hline & Irr & & 14 & 0.23 & 0.58 & & & & \\
\hline & Un & Brown & & 0.15 & 0.52 & $-27 \%$ & $12 \%$ & -3.1 & 4.6 \\
\hline & Irr & & 13 & 0.19 & 0.46 & & & & \\
\hline & Un & Brown & & 0.29 & 0.78 & $7 \%$ & $5.1 \%$ & 1.7 & 3.3 \\
\hline & Irr & & 12 & 0.27 & 0.74 & & & & \\
\hline & Un & Brown & & 0.29 & 0.62 & $-28 \%$ & $-19 \%$ & -8.0 & -12 \\
\hline & Irr & & 10 & 0.37 & 0.74 & & & & \\
\hline & Un & Recent & & 0.30 & 0.62 & $27 \%$ & $24 \%$ & 6.4 & 12 \\
\hline & Irr & (Orthens) & 12.5 & 0.22 & 0.47 & & & & \\
\hline & Un & Recent & & 0.17 & 0.25 & $18 \%$ & $-3.8 \%$ & 2.4 & -0.8 \\
\hline & Irr & & 12.5 & 0.14 & 0.26 & & & & \\
\hline \multirow[t]{2}{*}{ MW (mean) } & Un & & 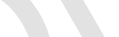 & 0.25 & 0.58 & $4.2 \%$ & $5.9 \%$ & 1.0 & 2.7 \\
\hline & Irr & & & 0.23 & 0.37 & & & & \\
\hline \multirow[t]{20}{*}{ Canterbury } & Un & $\begin{array}{l}\text { Pallic } \\
\text { (Aquepts) }\end{array}$ & 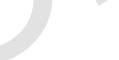 & 0.32 & 0.85 & $25 \%$ & $42 \%$ & 4.0 & 18 \\
\hline & Irr & & 20 & 0.24 & 0.49 & & & & \\
\hline & Un & Recent & & 0.27 & 0.60 & $-44 \%$ & $-20 \%$ & -20 & -20 \\
\hline & Irr & & 6 & 0.39 & 0.72 & & & & \\
\hline & Un & Gley & & 0.24 & 0.85 & $-7.7 \%$ & $15 \%$ & -2.0 & 11 \\
\hline & Irr & (Aquepts/Aquents) & 10 & 0.26 & 0.74 & & & & \\
\hline & Un & Pallic & & 0.26 & 0.93 & $-12 \%$ & $10 \%$ & -3.0 & 9.0 \\
\hline & Irr & & 10 & 0.29 & 0.84 & & & & \\
\hline & Un & Brown & & 0.18 & 0.64 & $5.6 \%$ & $17 \%$ & 0.7 & 7.3 \\
\hline & Irr & & 15 & 0.17 & 0.53 & & & & \\
\hline & Un & Pallic & & 0.35 & 1.26 & $20 \%$ & $35 \%$ & 8.8 & 55 \\
\hline & Irr & & 8 & 0.28 & 0.82 & & & & \\
\hline & Un & Recent & & 0.23 & 0.69 & $8.7 \%$ & $16 \%$ & 1.7 & 9.2 \\
\hline & Irr & & 12 & 0.21 & 0.58 & & & & \\
\hline & Un & Gley & & 0.23 & 0.58 & $8.7 \%$ & $-5.0 \%$ & 6.7 & -10 \\
\hline & Irr & & 3 & 0.21 & 0.61 & & & & \\
\hline & Un & Pallic & & 0.16 & 0.47 & $13 \%$ & $0.0 \%$ & 2.0 & 0.0 \\
\hline & Irr & & 10 & 0.14 & 0.47 & & & & \\
\hline & Un & Pallic & & 0.25 & 0.77 & $40 \%$ & $21 \%$ & 11 & 18 \\
\hline & Irr & & 9 & 0.15 & 0.61 & & & & \\
\hline
\end{tabular}


Table 2 (Continued)

\begin{tabular}{|c|c|c|c|c|c|c|c|c|c|}
\hline Region & & Soil order ${ }^{\mathrm{a}}$ & $\begin{array}{l}\text { Irrigation } \\
\text { duration } \\
\text { (years) }\end{array}$ & $\begin{array}{l}\text { Total mass of Cd } \\
\text { in } 0-0.1 \mathrm{~m}\left(\mathrm{~kg} \mathrm{ha}^{-1}\right)\end{array}$ & $\begin{array}{l}\text { Cumulative mass of } \\
\text { Cd in } \\
0-0.4 \mathrm{~m}_{\left(\mathrm{kg} \mathrm{ha}^{-1}\right)}\end{array}$ & $\begin{array}{l}\text { Total Cd } \\
\text { removed (\%) from } \\
0 \text { to } 0.1 \mathrm{~m}^{\mathrm{b}}\end{array}$ & $\begin{array}{l}\text { Total Cd } \\
\text { removed (\%) } \\
\text { from } \\
0 \text { to } 0.4 \mathrm{~m}\end{array}$ & $\begin{array}{l}\text { Total Cd removed from } \\
0 \text { to } 0.1 \mathrm{~m}\left(\mathrm{~g} \mathrm{ha}^{-1}\right. \\
\left.\mathrm{y}^{-1}\right)^{\mathrm{c}}\end{array}$ & $\begin{array}{l}\text { Total Cd removed from } \\
0 \text { to } 0.4 \mathrm{~m}\left(\mathrm{~g} \mathrm{ha}^{-1}\right. \\
\left.\mathrm{y}^{-1}\right)\end{array}$ \\
\hline $\begin{array}{l}\text { Canterbury } \\
\text { (mean) }\end{array}$ & Un & & & 0.25 & 0.76 & $5.7 \%$ & $13 \%$ & 1.0 & 9.8 \\
\hline Mean of all & Irr & & & 0.23 & 0.64 & $7.0 \%$ & $9.9 \%$ & 2.3 & 7.2 \\
\hline
\end{tabular}

a New Zealand soil classification (Hewitt, 1998) and Keys to soil taxonomy (Soil Survey staff, 2014).

b Difference between mass of Cd in irrigated and unirrigated areas divided by mass of $\mathrm{Cd}$ in unirrigated area.

c Difference between mass of $\mathrm{Cd}$ in irrigated and unirrigated areas divided by number of years of irrigation.

d Unirrigated.

e Irrigated. 
Table 3

Concentration and cumulative mass of $\mathrm{P}$ for different soil depths ( $P$ values $<0.05$ are bolded, numbers in the brackets are standard errors).

\begin{tabular}{|c|c|c|c|c|c|c|c|c|}
\hline \multirow[t]{2}{*}{ Depth (m) } & \multirow[t]{2}{*}{ Number of paired samples } & \multicolumn{3}{|c|}{ Mean concentration of $\mathrm{P}\left(\mathrm{mg} \mathrm{kg}^{-1}\right)$} & \multirow[t]{2}{*}{ Depth (m) } & \multicolumn{3}{|c|}{ Cumulative mass of $\mathrm{P}\left(\mathrm{kg} \mathrm{ha}^{-1}\right)$} \\
\hline & & Unirrigated & Irrigated & $P$ & & Unirrigated & Irrigated & $P$ \\
\hline $0-0.1$ & 22 & $803.0(67)$ & $712.0(73)$ & 0.014 & $0-0.1$ & $759.2(48)$ & $678.1(51)$ & 0.018 \\
\hline $0.1-0.2$ & 22 & $498.0(50)$ & $411.9(33)$ & 0.014 & $0-0.2$ & $1324.0(101)$ & $1144.3(82)$ & 0.006 \\
\hline $0.2-0.3$ & 22 & $290.1(31)$ & $247.0(27)$ & 0.091 & $0-0.3$ & $1697.4(136)$ & $1450.3(108)$ & 0.007 \\
\hline $0.3-0.4$ & 21 & $244.4(36)$ & $189.3(27)$ & 0.022 & $0-0.4$ & 2046.5 (177) & $1724.0(140)$ & 0.006 \\
\hline
\end{tabular}

Table 4

Concentration and cumulative mass of $\mathrm{U}$ for different soil depths ( $P$ values $<0.05$ are bolded, numbers in the brackets are standard errors).

\begin{tabular}{|c|c|c|c|c|c|c|c|c|}
\hline \multirow[t]{2}{*}{ Depth (m) } & \multirow[t]{2}{*}{ Number of paired samples } & \multicolumn{3}{|c|}{ Mean concentration of $\mathrm{U}\left(\mathrm{mg} \mathrm{kg}^{-1}\right)$} & \multirow[t]{2}{*}{ Depth (m) } & \multicolumn{3}{|c|}{ Cumulative mass of $\mathrm{U}\left(\mathrm{kg} \mathrm{ha}^{-1}\right)$} \\
\hline & & Unirrigated & Irrigated & $P$ & & Unirrigated & Irrigated & $P$ \\
\hline $0-0.1$ & 22 & $0.88(0.08)$ & $0.82(0.09)$ & 0.119 & $0-0.1$ & $0.84(0.08)$ & $0.81(0.09)$ & 0.299 \\
\hline $0.1-0.2$ & 22 & $0.70(0.10)$ & $0.66(0.10)$ & 0.069 & $0-0.2$ & $1.65(0.19)$ & $1.54(0.20)$ & 0.019 \\
\hline $0.2-0.3$ & 22 & $0.53(0.11)$ & $0.51(0.10)$ & 0.091 & $0-0.3$ & $2.31(0.32)$ & $2.16(0.31)$ & 0.012 \\
\hline $0.3-0.4$ & 21 & $0.49(0.13)$ & $0.49(0.12)$ & 0.385 & $0-0.4$ & $2.98(0.50)$ & $2.79(0.46)$ & 0.029 \\
\hline
\end{tabular}

The greatest difference in Cd concentration between the irrigated and unirrigated topsoil $(0-0.1 \mathrm{~m})$ in our study was in the Pumice Soil $\left(0.40 \mathrm{mg} \mathrm{kg}^{-1}\right)$, which may be due to the generally sandy nature and therefore greater potential for drainage in the Pumice Soil (Gray et al., 2003a). The annual average of Cd loss from each soil order from the $0-0.4 \mathrm{~m}$ depth was highest for Pallic Soil $\left(20.0 \mathrm{~g} \mathrm{ha}^{-1} \mathrm{yr}^{-1}\right)$ followed by Pumice $\left(7.4 \mathrm{~g} \mathrm{ha}^{-1} \mathrm{yr}^{-1}\right)$, Brown $\left(2.4 \mathrm{~g} \mathrm{ha}^{-1} \mathrm{yr}^{-1}\right)$, Gley $\left(0.5 \mathrm{~g} \mathrm{ha}^{-1} \mathrm{yr}^{-1}\right)$ and Recent $\left(0.1 \mathrm{~g} \mathrm{ha}^{-1} \mathrm{yr}^{-1}\right)$ soils (Table 2). The higher reported Cd loss in Pallic Soil was due to one sample with a Cd loss of $55 \mathrm{~g} \mathrm{ha}^{-1} \mathrm{yr}^{-1}$ (Table 2) which skewed the mean of Cd loss from Pallic Soil. Pumice Soil (sandy nature) showed the second highest loss of Cd.

In comparison to $\mathrm{Cd}$, the magnitude of the difference between $\mathrm{P}$ concentration and cumulative mass in irrigated and unirrigated soils was higher. The 'more significant' result for P than Cd may have been due to irrigation increasing downward movement of P more than Cd (Condron et al., 2006), or greater plant uptake and translocation of $\mathrm{P}$ than $\mathrm{Cd}$. The greater plant uptake was supported by Mackay et al. (1987) and Loganathan and Hedley (1997) who showed that at a fertilized site, the plant recovery of P (17-19\%) was greater than Cd (1.5-4.5\%).

There was no significant difference between the concentrations of $\mathrm{U}$ in irrigated and unirrigated soils. Therefore, in comparison to $\mathrm{Cd}, \mathrm{U}$ mobility was less influenced by irrigation, which was also concluded by McDowell (2010). The strong adsorption and minimal leaching of $U$ was also observed by Taylor (2007), who showed that almost all applied U in P fertilizers had been retained in the soil with minimal leaching. Taylor (1997) also concluded that less than $1 \%$ of added $U$ in soil was available for plant uptake or leaching. Rothbaum et al. (1979) and Heshmati-Rafsanjani (2009) also showed greater leaching and plant uptake of $\mathrm{P}$ than $\mathrm{U}$.

Because we used the same method for sampling in irrigated and unirrigated areas and due to no systematic difference in bulk density, or the variability of bulk density between irrigated and unirrigated areas, the probability that sampling or measurement error contributed to the significant differences observed between irrigated and unirrigated areas is low. Indeed if sampling or measurement error was high, the probability of detecting significant differences would be lower. While there was only significant difference at depths of $0-0.1$ and $0.1-0.2 \mathrm{~m}$ between concentration of $\mathrm{Cd}$ in irrigated and unirrigated areas, Cd concentrations were lower for all depth increments. This consistency of differences would have contributed to the cumulative mass differences being significant, which also would be the case for the significant difference between the cumulative mass of $U$ in irrigated and unirrigated areas while there was no significant difference observed for U concentration.

\subsection{Soil pH and carbon content}

Soil $\mathrm{pH}$ was approximately constant down the profile, as previously reported by McIntosh et al. (1997) and Gray et al. (2003a), with no significant differences between irrigated and unirrigated soils as was also reported by Condron et al. (2006). Although soils with lower C contents and lower $\mathrm{pH}$ might be expected to exhibit more Cd mobility (Gray et al., 1999a; McLaren et al., 2005), this was not observed here (due to moderate correlation between loss of $\mathrm{Cd}$ and loss of $\mathrm{C}$ and no significant correlation between the loss of $\mathrm{Cd}$ and the difference between the $\mathrm{pH}$ in irrigated and unirrigated areas) nor by Zanders et al. (1999b) or Gray et al. (2003a). Therefore, from our results none of the other measured soil properties (soil texture, $\mathrm{C}, \mathrm{pH}$ ) appeared to singly exert strong control on the mobility of $\mathrm{Cd}$ in soil. Cd mobility is expected to be a function of $\mathrm{pH}$, cation exchange capacity (CEC), Fe and Mn oxides, soil texture, organic carbon concentration, and the origin of anthropogenic Cd (Kim and Fergusson, 1992; Gray et al., 1999b, 2003b).

\subsection{Cadmium loss calculation}

The annual rate of Cd removal in irrigated areas in comparison to unirrigated areas $\left(2.3 \mathrm{~g} \mathrm{ha}^{-1}\right.$ from depth of $0-0.1 \mathrm{~m}$ and $5.5 \mathrm{~g} \mathrm{ha}^{-1}$ from depth of $0-0.2 \mathrm{~m}$ ) was greater than the reported amount of $\mathrm{Cd}$ leached in previous studies. For example, $1-2 \mathrm{~g} \mathrm{ha}^{-1} \mathrm{yr}^{-1}$ (top $0.2 \mathrm{~m}$, Cd loss determined from soil Cd concentration) (Tjell and Christensen, 1992); 0.27-0.86 $\mathrm{g} \mathrm{ha}^{-1} \mathrm{yr}^{-1}$ (top $0.25 \mathrm{~m}$, Cd loss determined from measuring leachate) (Gray et al., 2003a) and $2.44 .9 \mathrm{~g} \mathrm{ha}^{-1} \mathrm{yr}^{-1}$ (top $0.225 \mathrm{~m}$, Cd loss determined from measuring leachate) (Nicholson et al., 1996), and within the range of leaching loss reported in other studies: $2.4 \mathrm{~g} \mathrm{ha}^{-1} \mathrm{yr}^{-1}$ (top $0.075 \mathrm{~m}$, Cd loss determined from soil Cd concentration) (McDowell, 2012), 4.6-7.7 $\mathrm{g} \mathrm{ha}^{-1} \mathrm{yr}^{-1}$ (depth of $0 \mathrm{~cm}$ to top of E horizon, Cd loss determined from soil Cd concentration) (Zanders et al., 1999a). The range of variations could be attributed to the soil type, soil properties, and type of experiment (the measurement of Cd concentration in leachate or Cd concentration mesurement in soil profile). 
The 7\% loss of Cd from the $0-0.1 \mathrm{~m}$ depth (Table 2) only represents the Cd loss due to irrigation and the total amount of lost Cd (including Cd in parent material) may well be greater due to losses associated with rainfall, and/or plant and animal uptake that occur in both irrigated and unirrigated parts of pastures. Plant uptake of $\mathrm{Cd}$ in irrigated soils has also been shown to be greater than unirrigated soils (McDowell, 2012; Abraham et al., 2016), but plant uptake of Cd is generally less than Cd leaching (Zanders et al., 1999a). For example, Rothbaum et al. (1986) showed that about $2 \%$ of Cd added to grass-clover pastures in New Zealand was taken up by plants, while about $50 \%$ of added Cd was lost from the top $0.225 \mathrm{~m}$. Net Cd uptake by grazing animals is generally considered negligible, with more than $99 \%$ of Cd ingested by animals excreted (Van Bruwaene et al., 1984; Lee et al., 1994, 1996). Irrigation can also lead to higher rates of transpiration, which may also contribute in increasing Cd accumulation by plants (Legind et al., 2012). Thus, we hypothesize that Cd losses in our study were due to enhanced leaching and/or plant and animal uptake due to the extra water addition from irrigation.

The estimated 7\% loss of Cd from the top $0.1 \mathrm{~m}$ and about $10 \%$ of $\mathrm{Cd}$ loss from 0 to $0.4 \mathrm{~m}$ (Table 2) supported the results of previous studies that measured losses of about 5-15\% (depth of 0-0.25 m, natural or simulated rain) (Gray et al., 2003a) of added Cd due to leaching. Similarly, losses associated with leaching and plant and animal removal ranged from $10 \%$ (depth of $0-0.12 \mathrm{~m}$, non-irrigated) (Loganathan and Hedley, 1997) and 6\% (depth of 0-0.075 m, non-irrigated) (Williams and David, 1976). Therefore, our results from a range of soils and regions showed that although Cd was relatively immobile in soils, and the majority of applied Cd was adsorbed to the topsoil, irrigation can increase the loss of Cd.

\section{Conclusions}

The mean concentration of $\mathrm{Cd}$ in surface soil (0-0.1 and $0.1-0.2 \mathrm{~m}$ ) and cumulative mass to $0.4 \mathrm{~m}$ of unirrigated soils was significantly higher $(P<0.05)$ than the irrigated soils. The concentration of $P$ (all depths except for $0.2-0.3 \mathrm{~m}$ ) and the cumulative mass of $\mathrm{P}$ (all depths) in unirrigated soils was significantly greater $(P<0.05)$ than the irrigated soils. However, there was no significant difference between the concentration of $\mathrm{U}$ in irrigated and unirrigated soils. The significant difference in $\mathrm{P}$ and $\mathrm{Cd}$ concentration and nonsignificant difference in $\mathrm{U}$ concentration between irrigated and unirrigated soils, implies that irrigation probably had more effect on $\mathrm{P}$, and less effect on $\mathrm{U}$, losses relative to $\mathrm{Cd}$. The average rate of $\mathrm{Cd}$ loss from the topsoil $(0-0.1 \mathrm{~m})$ attributed to irrigation was $2.3 \mathrm{~g} \mathrm{ha}^{-1} \mathrm{yr}^{-1}$ and $7.2 \mathrm{~g} \mathrm{ha}^{-1} \mathrm{yr}^{-1}$ for $0-0.4 \mathrm{~m}$. We estimate that about $7 \%$ and $10 \%$ of Cd was lost from $0.1 \mathrm{~m}$ and $0.4 \mathrm{~m}$ depths, respectively. Therefore, it is concluded that $\mathrm{Cd}$ was generally immobile and preferably absorbs in the surface soil, and that $\mathrm{Cd}$ losses by irrigation are an important factor mitigating long-term $\mathrm{Cd}$ accumulation in agricultural soils.

\section{Acknowledgements}

We are grateful to DairyNZ for financial support for M. Salmanzadeh, and funding from Core funding for Crown Research Institutes (to Landcare Research) from the Ministry of Business, Innovation and Employment's Science and Innovation Group helped support P. L. Mudge and L. A. Schipper's contributions. Scott Fraser, Danny Thornburrow, Trevor Knight and Denis O' O'Conell for original site selection, soil sampling and sieving, and land owners and managers for allowing access for sampling.

\section{References}

Abraham, E., Cavanagh, J., Wood, P., Pearson, A., Mladenov, P., 2016. Cadmium in New Zealand's agriculture and food systems. In: Currie, L.D., Singh, R. (Eds.), Integrated Nutrient and Water Management for Sustainable Farming. Occasional Report No. 29. Fertilizer and Lime Research Centre, Massey University, Palmerston North, New Zealand. http://flrc.massey.ac.nz/publication.html.

Blakemore, L.C., Searle, P.L., Daly, B.K., 1987. Methods for Chemical Analysis of Soils. NZ Soil Bureau, Department of Scientific and Industrial Research, Lower Hutt, New Zealand.

Cavanagh, J., 2014. Status of Cadmium in New Zealand Soils. Landcare Research, Lincoln, New Zealand. http://www.fertiliser.org.nz/includes/download.aspx?ID =134299.

Condron, L.M., Sinaj, S., McDowell, R.W., Dudler-Guela, J., Scott, J.T., Metherell, A.K., 2006. Influence of long-term irrigation on the distribution and availability of soil phosphorus under permanent pasture. Aust. J. Soil Res. 44, 127-133.

Gray, C.W., McDowell, R.W., 2016. Cadmium losses from a New Zealand organic soil. N. Z. J. Agric. Res. 59, 185-193.

Gray, C.W., McLaren, R.G., Roberts, A.H.C., Condron, L.M., 1999. The effect of long-term phosphatic fertiliser applications on the amounts and forms of cadmium in soils under pasture in New Zealand. Nutr. Cycl. Agroecosys. 54, 267-277.

Gray, C.W., McLaren, R.G., Roberts, A.H.C., Condron, L.M., 1999. Solubility, sorption and desorption of native and added cadmium in relation to properties of soils in New Zealand. Eur. J. Soil Sci. 50, 127-137.

Gray, C.W., McLaren, R.G., Roberts, A.H.C., 2003. Cadmium leaching from some New Zealand pasture soils. Eur. J. Soil Sci. 54, 159-166.

Gray, C.W., McLaren, R.G., Shiowatana, J., 2003. The determination of labile cadmium in some biosolids-amended soils by isotope dilution plasma mass spectrometry. Aust. J. Soil. Res. 41, 589-597.

Health and Safety Executive, 1995. Approved list. information approved for the classification and labelling of substances and preparations dangerous for supply. HSE Booklet L61, second ed..

Heiler, T., 2008. Irrigation and Drainage - Irrigation Methods, Te Are - the Encyclopedia of New Zealand. http://www.TeAra.govt.nz/en/irrigation-and-drainage/page-6. (Accessed 28 September 2016).

Heshmati-Rafsanjani, M., 2009. Comparative Studies on the Solubility of Uranium and Phosphorus in Phosphate-Fertilisers and Their Uranium Transfer to Plants. Doctoral Dissertation. Technische Universitat Braunschweig, Braunschweig, Germany.

Hewitt, A.E., 1998. New Zealand Soil Classification. Manaaki Whenua Press, New Zealand

Irrigation New Zealand, 2013. New Zealand Irrigation Overview. Note 1. Christchurch, New Zealand.

Kim, N.D., Fergusson, J.E., 1992. Adsorption of cadmium by an aquent New Zealand soil and Its components. Aust. J. Soil. Res. 30, 159-167.

Lee, J., Grace, N.D., R, R.J., 1994. Cadmium accumulation in liver and kidney of sheep grazing ryegrass/white clover pastures. In: Proceedings of the New Zealand Society of Animal Production. New Zealand Society of Animal Production, New Zealand. pp. 31-34.

Lee, J., Rounce, J.R., Mackay, A.D., Grace, N.D., 1996. Accumulation of cadmium with time in Romney sheep grazing ryegrass-white clover pasture: effect of cadmium from pasture and soil intake. Aust. J. Agric. Res. 47, 877-894.

Legind, N., Rein, A., Serre, J., Brochier, A., Haudin, C.-S., Cambier, P., Houot, S., Trapp, S., 2012. Simultaneous simulations of uptake in plants and leaching to groundwater of cadmium and lead for arable land amended with compost or farmyard manure. PLoS One 7, 1-13.

Loganathan, P., Hedley, M.J., 1997. Downward movement of cadmium and phosphorus from phosphatic fertilisers in a pasture soil in New Zealand. Environ. Pollut. 95, 319-324.

Loganathan, P., Hedley, M.J., Grace, N.D., Lee, J., Cronin, S.J., Bolan, N.S., Zanders, J.M., 2003. Fertiliser contaminants in New Zealand grazed pasture with special reference to cadmium and fluorine - a review. Aust. J. Soil Res. 41, 501-532.

MAF (Ministry of Agriculture and Foresty), 2011. Cadmium and New Zealand Agriculture and Horticulture: A Strategy for Long Term Risk Management: A Report Prepared by the Cadmium Working Group for the Chief Executives Environmental Forum. Ministry of Agriculture and Foresty, Wellington, New Zealand. https://www.mpi.govt.nz/ document-vault/10073.

Mackay, A.D., Syers, J.K., Gregg, P.E.H., 1987. Potential losses of fertiliser phosphorus by animal transfer. Fertil. Res. 14, 125-134.

Martin, H.W., Kaplan, D.I., 1998. Temporal changes in cadmium, thallium, and vanadium mobility in soil and phytoavailability under field conditions. Water Air Soil Pollut. 101, 399-410.

McBride, M.B., Richards, B.K., Steenhuis, T., Russo, J.J., Sauvé, S., 1997. Mobility and solubility of toxic metals and nutrients in soil fifteen years after sludge application. Soil Sci. $162,487-500$

McDowell, R.W., 2010. Is cadmium loss in surface runoff significant for soil and surface water quality: a study of flood-irrigated pastures?. Water Air Soil Pollut. 209, 133-142.

McDowell, R.W., 2012. The rate of accumulation of cadmium and uranium in a long-term grazed pasture: implications for soil quality. N. Z. J. Agric. Res. 55, 133-146.

McIntosh, P.D., Hewitt, A.E., Giddens, K., Taylor, M.D., 1997. Benchmark sites for assessing the chemical impacts of pastoral farming on loessial soils in southern New Zealand. Agric. Ecosyst. Environ. 65, 267-280.

McLaren, R.G., Clucas, L.M., Taylor, M.D., 2005. Leaching of macronutrients and metals from undisturbed soils treated with metal-spiked sewage sludge. 3. Distribution of residual metals. Aust. J. Soil Res. 43, 159.

McLeod, M., Cavanagh, J., Carrick, S., 2015. Contaminant Leachinf Through Stony Soils. Landcare Research, Lincoln, New Zealand. http://www.landcareresearch.co.nz/ 
publications/innovation-stories/2015-stories/contaminant-leaching. (Accessed 16 March 2017).

Mortvedt, J.J., 1995. Heavy metal contaminants in inorganic and organic fertilizers. Fertil. Res. 43, 55-61.

Mudge, P.L., Kelliher, F.M., Knight, T.L., O'Connell, D., Fraser, S., Schipper, L.A., 2016. Irrigating grazed pasture decreases soil carbon and nitrogen stocks. Global Change Biol. 23, 945-954.

Nicholson, F.A., Jones, K.C., Johnston, A.E., 1996. Evidence for the Leaching of Surface Deposited Cadmium in Agricultural Soils. Fertilisers as a Source of Cadmium. Organisation for Economic Cooperation and Development, Parice, France, 218-231.

Parliamentary Commissioner for the Environment,, 2004. Growing for good: intensive farming. Sustainability and the New Zealand Environment Parliamentary Commissioner for the Environment, Wellington. p. 236. http://www.pce.parliament.nz/ media/pdfs/Growing-for-Good.pdf. (Accessed 22 August 2016).

Rothbaum, H.P., McGaveston, D.A., Wall, T., Johnston, A.E., Mattingley, G.E.G., 1979. Uranium accumulation in soils from long-continued applications of superphosphate. Eur. J. Soil Sci. 30, 147-153.

Rothbaum, H.P., Goguel, R.L., Johnston, A.E., Mattingly, G.E.G., 1986. Cadmium accumulation in soils from long-continued applications of superphosphate. J. Soil Sci. 37, 99-107.

Salmanzadeh, M., Balks, M.R., Hartland, A., Schipper, L.A., 2016. Cadmium accumulation in three contrasting New Zealand soils with the same phosphate fertilizer history. Geoderma Reg. 7, 271-278.

Schipper, L.A., Sparling, G.P., Fisk, L.M., Dodd, M.B., Power, I.L., Littler, R.A., 2011. Rates of accumulation of cadmium and uranium in a New Zealand hill farm soil as a result of long-term use of phosphate fertilizer. Agric. Ecosyst. Environ. 144, 95-101.

Singh, B.R., Myhr, K., 1997. Cadmium leaching from cadmium enriched fertiliser in field lysimeters. In: Proceedings of 4th International Conference on the Biogeochmistry of Trace Elements. International Society of Trace Element Biogeochemistry, Berkeley, CA. pp. $105-106$.
Soil Survey staff, 2014. Keys to Soil Taxonomy. USDA-Natural resources Conservation Service, Washington, DC.

Taylor, M.D., Kim, N., 2007. The fate of uranium contaminants of phosphate fertiliser. In: Proceedings of International Symposium Protecting Water Bodies from Negative Impacts of Agriculture: Loads and Fate of Fertiliser Drived from Uranium. Braunschweig, Germany.

Taylor, M.D., Kim, N.D., Hill, R.B., Chapman, R., 2010. A review of soil quality indicators and five key issues after 12 yr soil quality monitoring in the Waikato region. Soil Use Manag. 26, 212-224.

Taylor, M.D., 1997. The Fate of Uranium Contaminants of Phsophate Fertilizers in New Zealand. MSc Thesis. University of Waikato, Hamilton, New Zealand.

Taylor, M.D., 2007. Accumulation of uranium in soils from impurities in phosphate fertilisers. Landbauforschung Volkendrode 57, 133-139.

Tjell, J.C., Christensen, T.H., 1992. Sustainable management of cadmium in danish agriculture. In: Vernet, J.P. (Ed.), Impact of Heavy Metals on the Environment. Elsevier, Amsterdam, pp. 273-286.

Van Bruwaene, R., Kirchmann, R., Impens, R., 1984. Cadmium contamination in agriculture and zootechnology. Experientia 40, 43-52.

Williams, C.H., David, D.J., 1976. The accumulation in soil of cadmium residues from phosphate fertilisers and their effect on the cadmium content of plants. Soil Sci. 121, 86-93.

Zanders, J., Edwards, J., Tillman, R., Gregg, P., Hedley, M., Mackay, A.J.L., 1999. The accumulation and leaching of fertilizer-derived cadmium in a new zealand podzol soil. In: Wenzel, W.W., Adriano, D.C., Alloway, B., Doner, H.E., Keller, C., Lepp, N.W., Mench, M., Naidu, R., Pierzynski, G.M. (Eds.), 5th International Conference on the Biogeochemistry of Trace Elements. Vienna, Austria, pp. 424-425.

Zanders, J.M., Palmer, A.S., Lee, J., Hedley, M.J., Tillman, R.W., 1999. The source and distribution of cadmium in soils on a regularly fertilised hill-country farm. Soil Res. 37 667-678. 